Красинский Владислав Вячеславович

кандидат юридических наук, эксперт

Российского общественного института

избирательного права (РОИИП)

Источник опубликования: Красинский В.В. Успехи и проблемы «левых» на выборах в Германии // Государство и право. 2010. № 6. С. 93-100; www.krasinskiy.ru

\title{
УСПЕХИ И ПРОБЛЕМЫ «ЛЕВЫХ» НА ВЫБОРАХ В ГЕРМАНИИ
}

Прошедшие в 2004-2009 гг. выборы в ландтаги федеральных земель Германии стали демонстрацией успеха Левой партии (Die Linke) ${ }^{1} .13$ июня 2004 г. в Тюрингии Левая получила 26, 1\% голосов избирателей (в сравнении с предыдущими выборами 1999 г. прирост голосов составил 5,3 \%), 19 сентября 2004 г. в Бранденбурге Левая добилась лучшего результата в своей истории $-27,96 \%$, на проходивших в тот же день выборах в Саксонии 23,6\%, 26 марта 2006 г. в Саксонии-Ангальт - 24,1\% (прирост составил 3,7\%), 17 сентября 2006 г. в Берлине - 16,3\%, в Мекленбурге-Передней Померании $-16,8 \%{ }^{2}$.

Для восточных земель достижения «левых» не стали неожиданностью Партия - правопреемница СЕПГ-ПДС хорошо знакома избирателям бывшей ГДР. Ситуация в западных землях выглядит иначе ${ }^{4}$. Здесь «левые» смогли отобрать голоса у традиционных участников избирательного процесса, таких как социал-демократическая партия Германии (СДПГ), христианскодемократический и христианско-социальный Союз (ХДС/ХСС), свободнодемократическая партия (СвДП) и «Зеленые». 13 мая 2007 г. Левая получила 8,44\% голосов в Бремене (прирост голосов составил 6,7\%), 7 января 2008 г.

1 Левая партия - политическая партия в Германии, разделяющая ценности демократического социализма. Правопреемница единственной правящей партии ГДР - социалистической единой партии Германии (SEPD - СЕПГ), после вхождения ГДР в состав ФРГ в 1990 г. переименована в «партию демократического социализма» (PDS -ПДС), с 2005 г. - в «Левую партию. ПДС» (Linkspartei.PDS), с 2007 г. носит название «Левая» (Linke).

${ }^{2}$ Cм.: http://www.wahlrecht.de/ergebnisse/index.htm; http://www.wahlenindeutschland.de/abltw.htm.

3 «Восточные (новые) земли» - территории, входившие период раскола Германии (1949-1990) в состав ГДР (Бранденбург, Саксония, Саксония-Ангальт, Тюрингия, Мекленбург-Передняя Померания).

${ }^{4}$ «Западные (старые)» земли - территории, входившие период раскола Германии (1949-1990) в состав ФРГ. 
партия впервые преодолела 5\% заградительный барьер и прошла в ландтаги Нижней Саксонии $(7,1 \%)$ и Гессена $(5,1 \%)^{5} .24$ февраля 2008 г. на выборах в Гамбурге Левая завоевала голоса 6,4\% избирателей, а 18 января 2009 г. 5,4\% голосов в Гессене. Несмотря на то, что в ряде западных земель Левая не смогла преодолеть заградительный барьер, ее успех состоит в обретении собственного электората там, где раныше его никогда не было (например, 2,3\% голосов избирателей на выборах в Сааре 5 сентября 2004 г., 3,1\% голосов в Северном Рейне-Вестфалии 22 мая 2005 г., 2,6\% голосов в Рейнланд-Пфальце и 3, 1\% в Баден-Вюртемберге 26 марта 2006 г., 4,4\% голосов в Баварии 28 сентября 2008 г.) $)^{6}$.

В настоящий момент депутаты Левой представлены в 10 земельных парламентах и многочисленных муниципальных выборных органах (представительство на местном уровне облегчается отсутствием заградительного барьера на коммунальных выборах ${ }^{7}$ ).

На досрочных выборах в Бундестаг в 2005 г. Левая добилась лучшего результата в сравнении с «народными» партиями (Союз ХДС/ХСС и СДПГ) и сформировала четвертую по численности фракцию в Бундестаге. В западных землях Левая увеличила свою долю голосов более чем в два раза, а в восточно-германских землях по числу полученных голосов избирателей Левая вышла на второе место (после СДПГ).

${ }^{5}$ Согласно абзацу 6 параграфа 6 Федерального закона ФРГ «О выборах» от 23 июля 1993 г. (в ред. от 31 октября 2006 г.) в Бундестаге представлены партии, получившие 5\% голосов избирателей по всей Германии (т.н. заградительный барьер или процентная оговорка) либо одержавшие победу в трех одномандатных округах. 5\% заградительный барьер установлен также на земельных выборах (исключение составляют Союз избирателей южного Шлезвига в земле Шлезвиг-Гольштейн и Сорбская народная партия в земле Бранденбург, представленные в ландтагах указанных земель независимо от преодоления заградительного барьера).

${ }^{6}$ См.:http://www.wahlrecht.de/ergebnisse/index.htm;http://www.wahlenindeutschland.de/abltw.htm.

76 июля 1999 г. решением Конституционного суда земли Северный Рейн-Вестфалия № 14/98 (15/98) 5\% заградительный барьер на коммунальных выборах в данной земле был признан неконституционным. 13 февраля 2008 г. Федеральный конституционный суд Германии признал наличие 5\% оговорки на коммунальных выборах в земле Шлезвиг-Гольштейн противоречащим Основному закону. 10 апреля 2008 г. неправомерность 5\% оговорки на коммунальных выборах была подтверждена решением 22/05 Конституционного суда Тюрингии. 20 апреля 2008 г. заградительный барьер был отменен ландтагом Саара. В настоящее время 5\% заградительный барьер на коммунальных выборах частично сохранен лишь в Бремене.См.:http://www.wahlrecht.de/wahlpruefung/19990706.htm; http://www.bundesverfassungsgericht.de/entsc heidungen/ks20080213_2bvk000107.html; http://www.thverfgh.thueringen.de. 
По мнению ряда исследователей (Корина Эрмунтс, Андреа Фолькенс), Левая становится пятой ведущей партией (наряду с СДПГ, Союзом ХДС/ХСС, СвДП и «Зелеными») в партийной системе Германии ${ }^{8}$.

Можно сколько угодно спорить о социалистическом прошлом партии, рассуждать о ее протестном характере, критиковать идеологию, программу и руководство. Но убедительная статистика выборов заставляет обратить внимание на место и роль Левой партии в политическом спектре современной Германии.

С чем же связан «феномен» Левой партии?

Победы Левой в новых (восточных) землях имеют давнюю и прочную традицию. Начиная с земельных выборов 1994 г. Левая неизменно завоевывает симпатии восточных немцев $(18,7 \%$ голосов в Бранденбурге, 19,9 \% в Саксонии-Ангальт, 22,7\% в Мекленбурге-Передней Померании). Именно в восточных землях «левые» регулярно получают т.н. «прямые мандаты» (Берлин, Саксония, Бранденбург) ${ }^{9}$. Победы партии на федеральном и земельном уровнях были бы невозможны без надежных позиций первичных партийных организаций на местном уровне. Примером могут служить коммунальные выборы, состоявшиеся в Берлине в 2006 и 2008 гг., в результате которых Левая получила представительство в 10 из 12 районах Берлина. На коммунальных выборах 2006 г. в Мекленбурге-Передней Померании депутаты Левой прошли в органы местного самоуправления всех земельных районов.

Успех партии в восточных землях обусловлен не только ее политическими корнями (возникла на почве СЕПГ), но и сохраняющимися особенностями социальной структуры бывшей ГДР (профессиональной, конфессиональной, демографической и др.), которые учитываются партией.

\footnotetext{
${ }^{8}$ CM.: http://www.tagesschau.de/inland/landtagswahlen10.html.

${ }^{9}$ В соответствии с параграфами 4-7 Федерального закона ФРГ «О выборах» от 23 июля 1993 г. (в ред. от 31 октября 2006 г.) на выборах в Бундестаг каждый избиратель имеет два голоса. С помощью первого голоса он отдает предпочтение кандидату, которого он хотел бы видеть депутатом Бундестага от своего избирательного округа. Избранный таким образом по мажоритарной системе народный представитель получает «прямой мандат» (Direktmandat). Второй голос используется для голосования по партийным спискам.
} 
Например, доля безработных в Восточной Германии по состоянию на декабрь 2008 г. составляет 12,2 \%, в Западной - 6,2\%; численность рабочих в Западной Германии составляет около $30 \%$, в Восточной - 38\%; доля протестантов на Западе - 37\%, на Востоке - 22\%, доля католиков на Западе $42 \%$, на Востоке $-4 \%^{10}$. С учетом этого левые целенаправленно ориентируются на избирателей - безработных, представителей рабочих семей, активистов профсоюзов, в конфессиональном аспекте - на протестантов.

Завоевание партией электоральных предпочтений на Западе Германии (т.н. «расширение на запад» - Westerweiterung) связано с экономическим кризисом, ухудшением материального положения и условий жизни граждан, уменьшением государственного финансирования отраслей социальной сферы, переносом на население существенной части социальных расходов, соответствием партийных ценностей и программных заявлений ожиданиям широких слоев немецкого общества, партийной реорганизацией, харизмой партийных лидеров.

Основой успеха «левых» стала непопулярная политика социалдемократов (а затем и христианских демократов), направленная на реформирование системы социального страхования и рынка труда Германии (Agenda 2010, Hartz-4) ${ }^{11}$.

Реализация указанных реформ была сопряжена с переносом части социальных функций государства на плечи простых граждан. Снизился уровень правовой защиты от необоснованных увольнений, уменьшился размер пособий по безработице, возрос испытательный срок при приеме на работу новых сотрудников. Неоднократно повышался возраст выхода на пенсию. Были сокращены дотации на строительство или приобретение жилья

${ }^{10}$ См.: http://statistik.arbeitsamt.de/statistik; Kai Arzneimer. Wie entwickelt sich die Parteiidentifikation seit 1990? // http://www.kai-arzneimer.com

11 Сопредседатель Левой партии Оскар Лафонтен выдвинул 4 основных требования, соответствующие ожиданиям большинства граждан Германии: 1) вывод Бундесвера из Афганистана; 2) отмена реформы рынка труда (Харц-4); 3) отмена пенсий с 67 лет; 4) введение общефедерального минимального размера оплаты труда. Эти требования были закреплены в Программном документе Левой партии, принятом 24-25 марта 2007 г. в г. Дортмунд //http://die-linke.de/fileadmin/download/dokumente/programmatische_eckpunkte.pdf. 
для личного пользования. В 2004-2005 гг. активистами Левой партии были организованы массовые акции протеста против реформирования социальной сферы. В связи с высокой социальной активностью граждан и обострением обстановки в отдельных регионах Германии «левые» попали в поле зрения спецслужб (в первую очередь, контрразведки БФФ) $)^{12}$. Рост влияния «левых» стал рассматриваться в качестве индикатора социальной напряженности и показателя поддержки проводимого высшими должностными лицами Германии экономического и политического курса.

Существенную роль в успехе на выборах сыграли идеологические принципы и ценности партии. Наряду с традиционными социалдемократическими принципами и ценностями (солидаризм, товарищеские традиции, самоорганизация, ответственность перед обществом, тесные связи с профсоюзами, эмансипация женщин, экологическое обновление экономики, интернационализм в вопросах разоружения и в отношениях со странами третьего мира) система программных взглядов Левой партии имеет ряд особенностей ${ }^{13}$. К ним относятся:

- антикапитализм (противоречия капитализма рассматриваются в качестве глобальной угрозы мировому сообществу в 21 веке; провозглашается возможность законодательного обобществления земли, природных богатств и средств производства в целях социальной

${ }^{12}$ В соответствии с Федеральным законом ФРГ «О сотрудничестве Федерации и земель в вопросах защиты конституции и о Ведомстве по защите конституции» от 20 декабря 1990 г. (с изм. от 17 декабря 2008 г.) Das Bundesamt für Verfassungsschutz (BFV) - Ведомство по защите Конституции (БФФ) - является головным контрразведывательным органом Германии, осуществляющим функции политического розыска.

${ }^{13}$ Идеологические взгляды Левой партии изложены в преамбуле Устава, принятого 21-23 июня 1991 г. (с изм. от 17-19 января 1997 г., 7-9 апреля 2001 г., 17 июля 2005 г., 26 ноября 2006 г.), Программе, принятой на 8 съезде 26 октября 2003 г. в г. Хемниц (далее - Хемницкая программа). См.: Die Linkspartei. PDS. Statut // http://archiv2007.sozialisten.de/partei/parteitag/pt10at/pdf/statut_linkspartei_november2006.pdf; Das Programm der Linkspartei. PDS //http://archiv2007.sozialisten.de/partei/ dokumente/programm/index.htm. Перед объединением с западно-германской партией «Выборная альтернатива: работа и социальная справедливость» (ВАСГ) 24-25 марта 2007 г. в г. Дортмунд был принят обновленный Программный документ Левой партии Programmatische Eckpunkte-Programmatisches Gründungsdokument der Partei Die Linke (далее - Дортмундская программа) // http://die-linke.de/fileadmin/download/dokumente/programmatische_eckpunkte.pdf. 
справедливости и производства товаров общественной необходимости; ставится задача по преодолению капитализма) ${ }^{14}$;

- антиамериканизм (осуждается агрессивная внешнеполитическая доктрина США, выдвигаются призывы к сопротивлению Евросоюза имперской политике американской администрации и мировому диктату подконтрольных Соединенным Штатам организаций (НАТО, ВТО, МВФ, Международный банк) ${ }^{15}$;

- радикализм (обосновывается легитимное право граждан на сопротивление насилию и унижению достоинства человека ${ }^{16}$ );

- последовательное выражение интересов населения «новых» земель. В Хемницкой и Дортмундской Программах партия заявляет об особой ответственности за Восточную Германию, требует справедливости по отношению к населению восточных земель, прекращения дискриминации «восточных» немцев в продолжительности рабочего времени, оплате труда, размере пенсий ${ }^{17}$.

Сформулированные политические установки привлекли к Левой часть электората коммунистов, социал-демократов, «зеленых» - рабочих, служащих, студентов, безработных (по экспертным оценкам, до 10\% электората на Западе и около $30 \%$ на Востоке Германии $)^{18}$.

На выборах в Бундестаг 2005 г. Левая получила дополнительные голоса за счет включения восточно-германскими земельными союзами в свои избирательные листы западно-германских кандидатов от WASG (BACГ)

${ }^{14}$ См.: Разделы I.2, II Хемницкой программы, Раздел I Дортмундской программы Левой партии // http://archiv2007.sozialisten.de/partei/ dokumente/programm/index.htm;

http://dielinke.de/fileadmin/download/dokumente/programmatische eckpunkte.pdf.

15 См. с. 5 Раздела I, с. 15 Раздела III Дортмундской программы Левой партии // http://dielinke.de/fileadmin/download/dokumente/programmatische eckpunkte.pdf. Остальные ведущие партии ФРГ (СДПГ, Союз ХДС/ХСС, СВДП и «Зеленые») выступают за укрепление трансатлантических связей, подчеркивают особую значимость отношений Германии с США.

${ }^{16}$ См.: С. 6 Раздела I. 2 Хемницкой программы Левой партии // http://archiv2007.sozialisten.de/partei/ dokumente/programm/index.htm.

${ }^{17}$ См.: Разделы III и IV Хемницкой программы, раздел III Дортмундской программы Левой партии // http://archiv2007.sozialisten.de/partei/ dokumente/programm/index.htm;

http://dielinke.de/fileadmin/download/dokumente/programmatische_eckpunkte.pdf.

${ }^{18}$ См.: Stefan Berg, Petra Bornhöft. Das Linksgespenst // Der Spiegel. 11. Juli 2005. S.54. 
(Wahlalternative Arbeit und Soziale Gerechtigkeit - (Выборная альтернатива: работа и социальная справедливость), отколовшихся от СДПГ.

16 июня 2007 г. в состав Левой партии (бывшей восточно-германской Партии демократического социализма) влилась западно-германская ВАСГ, что позволило партии увеличить численность, расширить свою социальную базу, улучшить выборные перспективы на федеральном и земельном уровне. Важной составляющей успеха партии стали личные и деловые качества лидеров Левой - Оскара Лафонтена, имеющего более чем 40-летний опыт партийной работы в СДПГ, и талантливого адвоката-оратора Грегора Гизи.

Тем не менее, в германском политическом процессе Левая партия была и остается в «изоляции». Во всех органах народного представительства (кроме Берлина, где партия участвует в коалиции с социал-демократами) Левая находится в оппозиции. Подобная роль в политической системе Германии обусловлена нежеланием других партий сотрудничать с «левыми». Несмотря на отрицание Левой партией диктатуры как средства достижения прогресса, осуждение преступлений, совершенных от имени социализма и коммунизма, критику антидемократической политики и сталинских извращений социализма, в массовом сознании западных немцев партия продолжает считаться коммунистической ${ }^{19}$. В партийных кругах ведущих партий ФРГ существует мнение, что «конюшенный запах бывшей партии демократического социализма может только повредить» ${ }^{20}$. Упреки в коммунизме основываются также на том, что на местных выборах Левая нередко поддерживает баллотировку членов Германской коммунистической партии, которые с помощью ее избирательных листов были избраны более чем в 20 коммунальных парламентов ${ }^{21}$.

${ }^{19}$ См.: С. 2, 50 Хемницкой программы, с. 3 Дортмундской программы Левой партии.

${ }^{20}$ См.: Der Spiegel. 10. Oktober 2005. S.36.

${ }^{21}$ Необходимо отметить, что в ФРГ коммунистическая партия Германии (KPD) была признана антиконституционной и запрещена решением Федерального конституционного суда от 17 августа 1956 г. В отличие от представителей других политических партий Германии, «левые» критикуют данное решение Конституционного суда и ставят под сомнение его правомерность. Основанная в 1968 г. Германская коммунистическая партия (DKP) рассматривается БФФ в качестве правопреемницы KPD и находится под оперативным наблюдением как левоэкстремистская организация. 
Левая партия занимает непримиримую позицию по отношению к неолиберализму. Во введении к Хемницкой программе 2003 г. отмечается, что «неолиберальная политика превращения всех сфер жизни в прибыльные рынки и авторитарное, имперское, воинственное проведение этой политики разрушают завоевания двух с половиной столетий социальной борьбы». Подраздел 1 «Неолиберальные нападки» раздела II Хемницкой программы Левой партии целиком посвящен глубокому анализу современной социальной действительности и негативной роли неолиберализма. В разделе II Дортмундской программы 2007 г. осуждается деятельность неолиберальных сил по ликвидации социального государства, ослаблению профсоюзов, провоцированию конфликтов и новых империалистических войн. Левая выступает против власти капитала в лице могущественных ТНК и финансовых центров, защищает социальную справедливость, предлагает ограничить свободу рынка (что исключает возможность сотрудничества партии с «неолиберальными» ХДС/ХСС и СвДП) ${ }^{22}$.

Наиболее вероятный шанс для Левой - это партнерство с «зелеными» и социал-демократами. В качестве примера подобного взаимодействия приводится действующее коалиционное правительство Норвегии, состоящее из представителей социал-демократов, Левой партии и «зеленых» - т.н. «красно-красно-зеленый скандинавский пакт» ${ }^{23}$. О готовности сотрудничать с социал-демократами и «левыми» заявлял в сентябре 2007 г. заместитель председателя фракции «зеленых» в Бундестаге Юрген Триттин. Триттин тогда выразил мнение, что у «зеленых» и Левой партии существуют «значительные программные совпадения» ${ }^{24}$.

${ }^{22}$ См.: Markus Deggerich, Günther Latsch. Es geht nur um ihn // Der Spiegel. 12. September 2005. S.46; Der Spiegel. 10. Oktober 2005. S.36.

${ }^{23} \mathrm{~B}$ соответствии с политическими традициями Германии каждая политическая партия имеет свой цвет: СДПГ - красный, Левая - темно-красный, ХДС/ХСС - черный, СвДП - желтый, «Зеленые» - зеленый. Поэтому коалиция социал-демократов, Левой партии и «зеленых» в Германии получила бы название «красно-красно-зеленой».

${ }^{24}$ В рядах Левой партии идею коалиции с социал-демократами и «зелеными» активно поддерживают т.н. «левые реформисты» (Петра Пац, Штефан Либих, Ян Корте). Условия сотрудничества «левых»с другими политическими силами закреплены в разделе IV Дортмундской программы 2007 г. К ним относятся: уважение основополагающих принципов Левой партии, транспарентность, общественный диалог 
Сравнение программ и агитационных материалов партий подтверждает это. И «левые», и «зеленые» выступают за введение законодательного минимального размера оплаты труда, за повышение подоходного налога, за увеличение расходов на образование и научные исследования, за переход на обновляемые источники энергии, за отмену трехуровневой системы школьного образования. «Левые» и «зеленые», в отличие от ХДС/XСС, поддерживают идею мультикультурализма. В области европейской интеграции и те, и другие выступали за необходимость референдума по евроконституции. Однако две попытки Андреа Ипсиланти в октябре-ноябре 2008 г. в Гессене создать коалицию социал-демократов с «зелеными» при поддержке Левой партии потерпели неудачу из-за нежелания 4 депутатов земельного парламента от СДПГ сотрудничать с Левой партией ${ }^{25}$.

В СДПГ отвергают сотрудничество с «левыми» по ряду причин. Вопервых, в СДПГ считают Левую экстремистской и националистической партией. Например, Тобиас Дюрр сравнивает Левую с националистическими партиями DVU (Германский народный союз) и NPD (Националдемократическая партия Германии): «Это инертные партии, близкие в своем популизме, протекционизме и ностальгии по национал-социальному благоденствию» ${ }^{26}$. Похожие обвинения в адрес Левой выдвигал министр внутренних дел земли Бранденбург от ХДС Йорг Шёнбом: «Социалист Лафонтен ищет своих избирателей у неонацистов. Если он продолжит так делать, этим может заняться БФФ» ${ }^{27}$. Во-вторых, по мнению социалдемократов, действия Левой носят «чисто протестный характер», не предполагающий каких-либо альтернатив, что затрудняет возможность конструктивного сотрудничества ${ }^{28}$. В-третьих, партийные лидеры Левой

и прямое участие граждан в политике. См. также: Trittin hofft auf ein Linksbündnis // Frankfurter Allgemeine Zeitung. 1. September 2007.

${ }^{25}$ CM.: Ypsilanti scheitert auf dem Weg zur Macht // Frankfurter Allgemeine Zeitung. 3. November 2008; Drama in Hessen. Müntefering greift hessische SPD - Abweichler an // Der Spiegel. 3. November 2008.

${ }^{26}$ См.: Stefan Berg, Markus Deggerich, Andreas Wassermann. Operation Norwegen // Der Spiegel. 19. December 2005. S.40.

${ }^{27}$ См.: Stefan Berg, Petra Bornhöft. Das Linksgespenst // Der Spiegel. 11. Juli 2005. S.54.

28 Подобные опасения разделяет идеолог Левой и депутат Европарламента Андре Бри. См.: Stefan Berg, Markus Deggerich. Denken in Schwarz-Weiß // Der Spiegel. 30. Juli 2007. S.34. 
Грегор Гизи и Оскар Лафонтен рассматриваются как демагоги, не способные взять на себя политическую ответственность. Приводится аргумент, что оба занимали ответственные посты (Гизи был сенатором в Берлине по вопросам экономики, Лафонтен занимал пост министра финансов Германии), и оба «сбежали» со своих постов. В связи с этим, как полагают бывший генеральный секретарь СДПГ Клаус Уве Беннетер и член СДПГ Матиас Плацек, социал-демократам следует дистанцироваться от них ${ }^{29}$.

Наряду с проблемой политической коммуникации и поиска партнеров по коалиции партия испытывает трудности с кадровым составом. Большинство членов партии - члены бывшей Социалистической единой партии Германии (CEПГ - SED), достигшие в настоящее время пенсионного возраста. «Костяк» партии попросту вымирает. Поэтому перед всеми звеньями и организациями «левых» стоит задача привлечения молодежи, обновления и пополнения партийных рядов.

Другой острой проблемой партийного развития является оперативное изучение и разработка Левой партии Ведомством по защите Конституции (БФФ-BFV) и его земельными органами. В 2007-2008 гг. Левая партия находилась в разработке центрального аппарата немецкой контрразведки. В ряде «западных» земель (Нижняя Саксония, Баден-Вюртемберг, Гессен, Бавария) Левая партия рассматривается как «полулегальная» политическая организация и изучается компетентными органами безопасности в качестве объекта оперативного интереса. В «восточных» землях (бывшая ГДР) подобное наблюдение, как правило, не проводилось или было прекращено (например, в Бранденбурге или Мекленбурге - Передней Померании). В январе 2008 г. оперативная работа в отношении функционеров Левой партии была прекращена и в западной земле Саар. В остальных федеральных землях региональные власти занимают выжидательную позицию в отношении оперативного контроля политической деятельности партии, обосновывая

${ }^{29}$ См.: Medienhauptstadt Saarbrücken dank Oskar //www.saar-economy.com; Stefan Berg, Petra Bornhöft. Das Linksgespenst // Der Spiegel. 11. Juli 2005. S.54. 
свою «пассивность» отсутствием директивы Ведомства по защите Конституции и согласованной позиции земельных органов безопасности ${ }^{30}$. Заслуживает внимания судебная практика, связанная с обжалованием действий Ведомства по защите Конституции, направленных на проведение оперативно-розыскных мероприятий в отношении отдельных членов Левой партии. Так, 20 июня 2007 г. Федеральный конституционный суд Германии принял к производству жалобу заместителя председателя Левой фракции в Бундестаге депутата Бодо Рамелова на действия БФФ по осуществлению наружного наблюдения за ним в период его деятельности в качестве депутата ландтага Тюрингии и депутата Бундестага ${ }^{31}$. На основе анализа программы Левой партии, публикаций и заявлений ее руководства административный суд Кельна пришел к выводу, что деятельность партии не носит антиконституционного или экстремистского характера и своим решением от 13 декабря 2007 г. № 20 К 3077/06 подтвердил незаконность наблюдения БФФ за депутатом Бодо Рамеловым ${ }^{32}$.

Сразу после завершения федеральных выборов в Бундестаг в 2005г. партия испытала мощное давление со стороны СМИ в связи с т.н. «проблематикой государственной безопасности» (MFS-Problematik ${ }^{33}$ ).

30 Различная позиция компетентных органов в отношении деятельности Левой партии может объясняться тем, что она политически неоднородна. В структуре партии существует несколько идейных течений и ответвлений (например, «коммунистическая платформа» или «марксистский форум»), отдельные представители которых не отрицают возможность использования экстремистских методов завоевания и использования политической власти.

${ }^{31}$ См.: Miriam Hollstein. Linke reicht Klage gegen Bundesregierung ein // Die Welt. 21. Juni 2007.

${ }^{32}$ В соответствии с ч. 2 ст. 21 Основного закона ФРГ «партии, которые по своим целям или действиям своих сторонников стремятся причинить ущерб основам свободного демократического строя или устранить его либо поставить под угрозу существование Федеративной республики Германии, являются антиконституционными. Вопрос об антиконституционности решает Федеральный конституционный суд. Правовые последствия, связанные с признанием партии антиконституционной, детализированы в параграфах 32-33 раздела 7 Федерального закона ФРГ от 24 июля 1967 г. (с изм. от 22 декабря 2004 г.) «О политических партиях». См. http://www.justiz.nrw.de/nrwe/ovgs/vg_koeln/j2007/20_K 3077_06urteil20071213.html; $\quad$ Beobachtung von Linkspartei-Politiker verboten // Die Welt. 17. Januar 2008.

33 Das MFS (Ministerium für Staatssicherheit) - Министерство государственной безопасности ГДР («Штази»). Министерство осуществляло разведку, контрразведку, политический розыск и следствие. Оно провело ряд блестящих операций по проникновению в органы власти (МИД ФРГ, Ведомство федерального канцлера, Бундесвер), спецслужбы (БНД, МАД, БФФ), политические партии (ХДС, СДПГ) Федеративной республики Германии. Наиболее известной операцией «штази» стало создание разведывательных позиций в Ведомстве федерального канцлера (сотрудник «штази» Гюнтер Гийом находился на должности референта федерального канцлера Вилли Брандта, что привело последнего к отставке в 1974 г.). 
Руководящее партийное звено федерального и земельного уровней обвинялось в сотрудничестве со «штази» (Stasi-Vorwürfe) $)^{34}$.

Одному из председателей Левой - Лотару Биски - инкриминировалось многолетнее сотрудничество с органами госбезопасности на конфиденциальной основе. Приводился даже оперативный псевдоним Биски, якобы обнаруженный в архиве «штази» ${ }^{35}$.

Ландтаг Саксонии инициировал расследование в отношении руководителя земельной левой фракции Петера Порша, в отношении которого было выдвинуто обвинение в сборе информации для «штази» в 70-

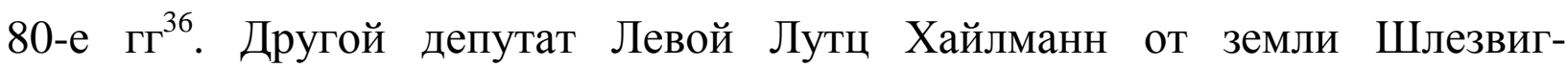
Гольштейн при выдвижении в качестве кандидата скрыл данные о том, что он служил охранником на объекте Министерства государственной безопасности ГДР ${ }^{37}$.

18 февраля 2008 г. депутат Левой в ландтаге Нижней Саксонии Кристель Вегнер была исключена из фракции за положительные высказывания в адрес «штази». Сопредседатель левой фракции в Бундестаге Грегор Гизи, которому в 90-е гг. удалось отклонить обвинения в сотрудничестве со «штази», обвинил Вегнер в том, что она является агентом - провокатором контрразведки БФФ $\Phi^{38}$.

В связи с этим необходимо упомянуть проблему т.н. люстрации, существующую в ряде стран Центральной и Восточной Европы (Польша, Албания, Чехия, Венгрия, Латвия, Литва, Германия). Законодательство европейских государств, входивших в состав «социалистического лагеря» обязывает кандидатов на выборные должности представлять декларации о сотрудничестве с органами государственной безопасности, разведки или

${ }^{34}$ Истоки подобных обвинений связаны с тем, что в ГДР «штази» считалась «щитом и мечом» социалистической единой партии Германии (СЕПГ), правопреемницей которой выступает Левая партия.

35 См.: Akte Bisky: «Ein zuverlässiger Genosse» // Frankfurter Allgemeine Zeitung. 23. September 2005; Stasi-Akte Bisky, Die Sache mit «IM Bienert» // Der Stern. 20. Oktober 2005.

${ }^{36}$ См.: Birthler fordert Stasi Überprüfung der neuen Abgeordneten // Frankfurter Allgemeine Zeitung. 23. September 2005.

37 Cм.: Linkspartei - Mann arbeitete für die Stasi // Der Spiegel. 8. Oktober 2005; Personenschützender Parlamentarier // Die Tageszeitung. 10. Oktober 2005.

${ }^{38}$ См.: Abgeordnete fordert Stasi reloaded // Süddeutsche Zeitung. 14. Februar 2008; Linke schließt DKPPolitikerin aus // Der Stern. 18. Februar 2008. 
контрразведки. Например, в Польше в соответствии с Законом от 11 апреля 1997 г. «О выявлении фактов работы либо службы в органах государственной безопасности либо сотрудничества с ними лиц, исполняющих публичные функции, в период 1944-1990 годы» кандидат должен внести в Государственную избирательную комиссию декларацию о своей работе либо сотрудничестве с органами государственной безопасности. Если лицо уже проходило такую проверку, оно ставит об этом в известность Государственную избирательную комиссию. Для проверки достоверности и выявления такого рода сведений были созданы суды люстрации ${ }^{39}$.

Аналогичная процедура проверки кандидатов предусмотрена в Албании.

Согласно Закону Чешской республики от 4 октября 1991 г. «О незаконности коммунистического режима» лица, сотрудничавшие с коммунистическим режимом в 1948 - 1989 гг., лишаются на пять лет права занимать государственные должности.

В Венгрии люстрация носила «мягкий» характер. В декабре 1994 г. Конституционный суд Венгрии ограничил круг проверяемых лиц и возможности использования сведений, представляемых для общественности.

Закон Латвии «О выборах» от 22 октября 1992 г. предусмотрел для кандидатов в депутаты парламента необходимость подачи письменного заявления о наличии или отсутствии связей с советскими органами государственной безопасности. С 1995 г. на выборах в Сейм действует запрет на избрание бывших членов КПСС, а также работников и агентов КГБ.

В Литве был принят закон «О проверке мандатов депутатов, подозреваемых в сознательном сотрудничестве со специальными службами СССР или других государств». Для проверки и расследования фактов подобного сотрудничества предусматривалось создание специальных депутатских комиссий ${ }^{40}$.

\footnotetext{
${ }^{39}$ См.: Современные избирательные системы. Вып. 1: Великобритания, Канада, Мексика, Польша. М.: Норма, 2006. С. 392-393.

${ }^{40}$ См.: В. Бойц̧ова, Л. Бойц̧ова. Люстрация в Центральной и Восточной Европе // Правозащитник. 1999. № 3.
} 
В Германии по Закону «О документации Министерства государственной безопасности бывшей ГДР» (Gesetz über die Unterlagen des Staatssicherheitsdienstes der ehemaligen Deutschen Demokratischen Republik) от 20 декабря 1991 г. государственные органы получили право запрашивать из архива «штази» информацию о соискателях на государственные должности ${ }^{41}$. Наличие данных о сотрудничестве со спецслужбами ГДР рассматривается как основание для отказа в приеме на работу или увольнения с работы.

Как видно из приведенных ранее примеров, архив «штази» активно используется официальными властями Германии для дискредитации восточно-германских политиков - представителей Левой партии.

Вместе с тем, ограничение или лишение субъективных прав по профессиональному признаку, осуществляемое в порядке люстрации, как представляется, носит дискриминационный и недемократический характер. Противоправность люстрационных законов обусловлена тем, что они во внесудебном порядке ухудшают правовое положение субъектов права и распространяют свою юридическую силу на правоотношения, возникшие до момента их принятия. Необходимость устранения подобных дискриминационных мер подтверждается положениями статьи 14 Европейской Конвенции о защите прав человека от 4 ноября 1950 г., статьями 25 и 26 Международного пакта о гражданских и политических правах от 16 декабря 1966 г., пунктами 5.9, 7.5, 7.7 части 1 Документа Копенгагенского Совещания Конференции по человеческому измерению СБСЕ от 26 июня 1990 г., статьями 20 и 21 Хартии Европейского Союза об основных правах от 7 декабря 2000 г., резолюциями Парламентской ассамблеи Совета Европы № 1547 и 1791, принятыми 18 апреля 2007 г. и содержащими рекомендации о развитии демократии и совершенствовании защиты прав человека в государствах-членах Совета Европы. В указанных документах отмечается необходимость расширить права всех граждан на

\footnotetext{
${ }^{41}$ CM.: http://bundesrecht.juris.de/stug/index.html.
} 
участие в политической жизни, сократить категории лиц, лишенных права избирать и быть избранными, ликвидировать любые проявления дискриминации, улучшить представительность парламентов ${ }^{42}$.

Исключительно важное значение для соблюдения демократических прав и свобод человека и гражданина имеют документы Парламентской ассамблеи Совета Европы и решения Европейского Суда по правам человека, связанные с развитием и защитой политического плюрализма и многопартийности.

В пункте 11 Резолюции 1308 (2002) Парламентской ассамблеи Совета Европы «Об ограничениях на деятельность политических партий в государствах - членах Совета Европы» отмечается, что «политический плюрализм является одним из основополагающих принципов демократического устройства» ${ }^{43}$. В Резолюции 1407 (2004) «О новых концепциях оценки состояния демократического развития» политический плюрализм и состояние функционирования политических партий названы в качестве показателей демократического развития Европы ${ }^{44}$. Пункт 5 Резолюции 1546 (2007) «Кодекс поведения политических партий» содержит положение о том, что «политические партии являются ключевым элементом выборной конкуренции. Легитимность и авторитет политических партий имеют важнейшее значение для легитимности демократического процесса в целом. Нарушение их нормальной деятельности может нанести ущерб всей демократической системе и ее отдельным институтам» ${ }^{45}$.

В Резолюции 1547 (2007) «О состоянии прав человека и демократии в Европе» Парламентская ассамблея напоминает о праве оппозиционных политических партий и их членов инициировать парламентские расследования, созывать специальные заседания парламента, а также об

\footnotetext{
${ }^{42}$ CM.: http://www.coe.int/T/r/Parliamentary_Assembly

${ }^{43}$ См.: Международные избирательные стандарты. Сб. документов. М.: Издательство Весь Мир, 2004. C. 596.

${ }^{44}$ Cм.: http://www.coe.int/t//r/Parliamentary_Assembly

${ }^{45}$ Там же.
} 
обязанности оппозиции проявлять ответственность и стремиться повышать эффективность работы парламента ${ }^{46}$.

Существенное влияние на институционализацию политических партий и защиту многопартийности оказывает практика Европейского Суда по правам человека.

В соответствии с Конвенцией о защите прав человека и основных свобод 1950 г. Европейский Суд призван обеспечивать неукоснительное соблюдение и исполнение норм Конвенции ее государствами-участниками. Он осуществляет эту задачу путем рассмотрения и разрешения конкретных дел, принятых им к производству на основе индивидуальных жалоб, поданных физическим лицом, группой лиц или неправительственной организацией. Возможна также подача жалобы на нарушение Конвенции государствомчленом Совета Европы со стороны другого государства-члена. Европейский Суд не является высшей инстанцией по отношению к судебной системе государства - участника Конвенции. Поэтому он не может отменить решение, вынесенное органом государственной власти или национальным судом, не дает указаний законодателю, не осуществляет контроль национального законодательства. Однако нередко значимость решений Суда выходит за национальные пределы, воздействуя на право и судебную практику и других государств - участников Конвенции.

Европейский Суд по правам человека неоднократно подчеркивал в своих решениях, что политические партии играют существенную роль в обеспечении идеологического многообразия и успешного развития демократии. В своем решении по делу «Объединенная коммунистическая партия и другие против Турции» от 30 января 1998 г. Европейский Суд по правам человека постановил, что «политические партии представляют собой форму ассоциации, жизненно необходимую для надлежащего функционирования демократии» ${ }^{47}$.

\footnotetext{
46 Там же.

${ }^{47}$ CM.: http://www.echr.coe.int
} 
В пунктах 42 и 45 Решения по делу «Социалистическая партия и другие против Турции» от 25 мая 1998 г. Европейский Суд по правам человека отметил, что «деятельность политических партий является коллективной реализацией свободы выражения мнений». Учитывая, что демократия невозможна без свободы выражения мнений, «с этой точки зрения не может быть никакого оправдания созданию препятствий политической группе исключительно потому, что она стремится обсуждать публично ситуацию, затрагивающую часть населения государства, и участвовать в политической жизни страны, чтобы, руководствуясь демократическими правилами, найти решения, способные удовлетворить каждого заинтересованного человека» ${ }^{48}$.

В Решении «Фогт против Германии» от 26 сентября 1995 г. Суд подтвердил, что деятельность по поручению незапрещенной судом политической партии является правомерной политической деятельностью легальной партии ${ }^{49}$.

В контексте названных международных документов и решений Европейского Суда по правам человека дискриминационные меры в отношении Левой партии и ее членов представляются не вполне обоснованными.

Попытки Правительства ФРГ с помощью репрессивных люстрационных процедур и оперативного наблюдения спецслужб ограничить политическую активность Левой партии (за которыми скрывается страх перед «левым» движением и нежелание менять сложившуюся партийную систему) в сочетании с непопулярным социально-экономическим курсом немецкого руководства ведут лишь к усилению роли Левой партии в политическом спектре Германии.

Таким образом, партийное развитие «левых» в современных условиях испытывает на себе влияние не только поставленных руководством амбициозных задач по закреплению своего традиционного влияния в

${ }^{48}$ См.: Международные избирательные стандарты. Сб. документов. М.: Издательство Весь Мир, 2004. C. $724-725$.

${ }^{49}$ Там же. С. 687-703. 
восточных землях и завоеванию электората на западе Германии, обновлению и расширению партийных рядов, но и продолжающейся практики люстрации, сопровождающейся оперативно-розыскной и контрразведывательной деятельностью спецслужб Германии в отношении партийных активистов и функционеров Левой. Данные обстоятельства обусловливают необходимость скорейшей легализации партии во всех федеральных землях, что позволило бы ее членам и руководству не только беспрепятственно осуществлять законную политическую деятельность, но и создавать коалиции с ведущими партиями.

Красинский Владислав Вячеславович кандидат юридических наук, эксперт Российского общественного института избирательного права (РОИИП)

Источник опубликования: Красинский В.В. Успехи и проблемы «левых» на выборах в Германии // Государство и право. 2010. № 6. С. 93-100. 